${ }^{\odot}$ Н. Ю. Щербатюк, I. М. Горішний, М. І. Горішний

ДВНЗ «Тернопільсъкий державний медичний університет ілені І. Я. Горбачевсъкого МОЗ України»

\title{
МЕМБРАНОДЕСТРУКТИВНІ ПРОЦЕСИ ТА СИСТЕМА АНТИОКИСНЮВАЛЬНОГО ЗАХИСТУ ПРИ ЗАЛІЗОДЕФІЦИТНІЙ АНЕМІЇ В ДІТЕЙ (ОГЛЯД ЛІТЕРАТУРИ)
}

У статті представлено численні дані літератури про активацію перекисного окиснення ліпідів за різної патології в дитячому віці. Надлишок заліза в організмі може бути ініціатором оксидазних реакцій, причиною збільшення продукції гідроксильних радикалів, які пошкоджують клітини. Це дає підставу віднести анемію до захворювань, що характеризуються мембранною патологією. Встановлено, що десріцит заліза, поряд із широким спектром відомих негативних впливів на організм, активує процеси вільнорадикального окиснення в тканинах і призводить до розбалансованості в антиоксидантній системі захисту. Виявлено корелятивну залежність між дефріцитом заліза і концентрацією кінцевого продукту ліпопероксидації - малонового діальдегіду: при зниженні заліза рівень його збільшувався, тобто залізо було каталізатором перекисного окиснення ліпідів. Мембранодеструктивні й метаболічні зміни в еритроциті, які виникають внаслідок активації вільнорадикального окиснення ліпідів і зміни активності антиокиснювальних фрерментів, пригнічують його функціональну активність, що сприяє наростанню гіпоксії та накопиченню в організмі токсичних метаболітів.

Ключові слова: антиоксидантна система захисту; перекисне окиснення ліпідів; малоновий діальдегід; залізодесріцитна анемія.

МЕМБРАНОДЕСТРУКТИВНЫЕ ПРОЦЕССЫ И СИСТЕМА АНТИОКИСЛИТЕЛЬНОЙ ЗАЩИТЫ ПРИ ЖЕЛЕЗОДЕФИЦИТНОЙ АНЕМИИ У ДЕТЕЙ (ОБЗОР ЛИТЕРАТУРЫ)

В статье представлены многочисленные данные литературы об активации перекисного окисления липидов при различной патологии в детском возрасте. Избыток железа в организме может быть инициатором оксидазных реакций, причиной увеличения продукции гидроксильных радикалов, которые повреждают клетки. Это дает основание отнести анемию к заболеваниям, характеризующимся мембранной патологией. Установлено, что десрицит железа, наряду с широким спектром известных негативных воздействий на организм, активирует процессы свободнорадикального окисления в тканях и ведет к разбалансированности в антиоксидантной системе защиты. Выявлено коррелятивную зависимость между десрицитом железа и концентрацией конечного продукта липопероксидации - малонового диальдегида: при снижении железа уровень его увеличивался, то есть железо выступало катализатором перекисного окисления липидов. Мембранодеструктивные и метаболические изменения в эритроците, которые возникают вследствие активации свободнорадикального окисления липидов и изменения активности антиокисляющих ферментов, подавляют его фуннциональную активность, что способствует нарастанию гипоксии и накоплению в организме токсических метаболитов.

Ключевые слова: антиоксидантная система защиты; перекисное окисление липидов; малоновый диальдегид; железодесрицитная анемия.

MEMBRANE-DESTRUCTIVE PROCESSES AND ANTIOXIDANT DEFENSE SYSTEM AT IRON DEFICIENCY ANEMIA IN CHILDHOOD

The article presents numerous literature data on the activation of lipid peroxidation at various pathologies in childhood. Excess of iron in the body may be the initiator of oxidation reactions, the cause of an increase production of hydroxyl radicals that damage the cells, which gives grounds to belong anemia to the diseases that are characterized by membrane pathology. It was established that iron deficiency with a wide range of known negative influences on the body, activates the processes of free radical oxidation in tissues and leads to imbalance in antioxidant defense system. The correlation dependence between iron deficiency and concentration of the final products of lipid peroxidation was discovered - malonic dialdehyde: when iron decreased, the level of malonic dialdehyde increased so iron acts as a catalyst for lipid peroxidation. Membrane-destructive and metabolic changes in erythrocytes which arise as a result of the activation of free radical oxidation of lipids and changes in the activity of antioxidant enzymes inhibit its functional activity, that contributes to the growth of hypoxia and the accumulation of toxic metabolites in the body.

Key words: antioxidant defense system; lipid peroxidation; malonic dialdehyde; iron deficiency anemia.

З огляду на сучасні дані, більшість захворювань тією або іншою мірою пов'язана з ураженням клітинних мембран.

Плазматичні та внутрішньоклітинні мембрани виконують ряд важливих фрункцій в організмі. Зокрема, 3 біомембранами пов'язані процеси високоесективного каталізу багатоланцюгових біологічних реакцій, синтез білка, ліпопротеїнів, активація гідролітичних процесів [1-9]. Біологічні мембрани визначають рецепцію клітин, іонну проникність, елімінацію метаболітів [10-12].
Серед фракторів, що викликають порушення нормального функціонування біологічних мембран, важливе значення має активація перекисного окиснення ліпідів (ПОЛ). Інтенсифрікацію вільнорадикального окиснення ліпідів визнано універсальною патогенетичною ланкою в розвитку різних захворювань і патологічних процесів [13-20].

Відомо, що структурна цілісність і фрункціональна активність біомембран, у тому числі й еритроцитарних, залежать від концентрації перекису ліпідів та потужнос- 
ті антиоксидантної системи захисту (АОС3) [21-25]. У надлишку продукти ПОЛ є хімічно агресивними та високоруйнівними речовинами. Вони змінюють поверхню заряду та ступінь гідрофрільності ліпідного шару мембран, інактивують ряд ферментів, інгібують тканинне дихання, окиснюють сульсргідрильні сполуки, що, врешті-решт, може спричинити не тільки підвищену проникність мембран, але і загибель клітин [26, 27]. Так, вихід фрерментів із лізосом внаслідок утворення в їх мембранах гідрофільних

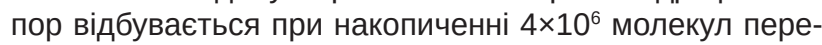
кису ліпідів на одну лізосому, гемоліз еритроцитів - при накопиченні $1,6 \times 10^{5}$ молекул, а для набряку і лізису мітохондрій потрібно 1,8×109 молекул $[28,29]$.

У сучасній літературі різке (патологічне) підсилення перекисного окиснення ліпідів визначається поняттям «окиснювальний стрес» [30]. Регуляція процесів ПОЛ здійснюється антиоксидантною системою, де провідну роль відіграє пул антиокиснювальних фрерментів - супероксиддисмутази, каталази, глутатіонпероксидази, глутатіонредуктази. Із вказаними орерментами взаємодіють ендо- й екзогенні антиоксиданти неферментативної природи (токофероли, біофлавоноїди, каротиноїди). За АОСЗ несуть відповідальність також білки - церулоплазмін, трансорерин. При патології рівновага між ПОЛ і потужністю АОСЗ зміщується, порушується гомеостаз, і ПОЛ інтенсифрікується в результаті некерованих антиокиснювальних реакцій.

Численні дані літератури свідчать про активацію пол за різної патології в дитячому віці [31-39], однак механізм ПОЛ і стан фрерментів АОСЗ у дітей при залізодефіцитній анемії (ЗДА) в літературі викладено обмежено, дані нерідко мають суперечливий характер. Зокрема, залишається до кінця не визначеною роль самого заліза в процесах ПОЛ.

У літературі $є$ дані, які вказують на те, що надлишок заліза в організмі (гемохроматози, таласемія) може бути ініціатором оксидазних реакцій, причиною збільшення продукції гідроксильних радикалів, які пошкоджують клітини [40].

При вивченні процесів ПОЛ у дорослих із рефрактерними анеміями, що, як відомо, супроводжуються накопиченням у тканинах заліза, встановлено значне підвищення малонового діальдегіду і зниження антиокиснювальної здатності плазми. Ці зміни автори пов'язують із оксидантною дією пулу заліза, не пов'язаного з трансферином.

Разом із тим, упродовж останніх років встановлено, що дефіцит заліза, поряд із широким спектром відомих негативних впливів на організм, активує процеси вільнорадикального окиснення в тканинах і призводить до розбалансованості в АОСЗ.

Так, експериментально доведено, що при глибокому аліментарному дефіциті заліза значно знижувалась активність ключового антипероксидного ферменту еритроцитів - глутатіонпероксидази, який здатний, крім $\mathrm{H}_{2} \mathrm{O}_{2}$, нейтралізувати широкий спектр органічних гідроперекисів, включаючи і гідроперекиси жирних кислот. Паралельно зменшенню глутатіонпероксидази підвищувався рівень малонового діальдегіду, знижувався гемоглобін у крові, зменшувалися об'єм еритроцита і концентрація в ньому гемоглобіну. Це дало можливість зробити висновок, що зниження активності глутатіонпероксидази $€$ явищем вторинним, яке виникає через дефіцит заліза як пластичного матеріалу.

Виявлено корелятивну залежність між дефіцитом заліза і концентрацією кінцевого продукту ліпопероксидації - малонового діальдегіду: при зниженні заліза рівень його збільшувався, тобто залізо, на думку автора, було каталізатором ПОЛ.

$€$ дані про те, що вже при латентному дефіциті заліза спостерігаються активація процесів ПОЛ і зміна в АОСЗ. Отже, дві крайні ситуації пов'язані з метаболізмом заліза (в одному випадку надлишок, а в іншому - дефіцит), можуть приводити до однакового результату - інтенсисрікації процесів вільнорадикального окиснення.

Більшість авторів схильна вважати, що одним з основних фракторів активації пОЛ при ЗДА є розвиток гіпоксії. За сучасними уявленнями, гіпоксію визнано станом внутрішньоклітинного метаболізму, при якому синтез АТФ лімітований внутрішньомітохондріальним вмістом кисню. Таке лімітування значною мірою може бути зумовлене станом червоної крові. Зниження числа еритроцитів і гемоглобіну, що є патофрізіологічною сутністю анемії, здатне значно зменшувати надходження кисню до тканин. Гіпоксія сприяє оксигеназному шляху утилізації кисню в тканинах, при якому повного 4-електронного відновлення кисню не відбувається і утворюються активні фрорми кисню $\left(\mathrm{O}_{2} \cdot, \mathrm{H}_{2} \mathrm{O}_{2}, \mathrm{OH} \cdot\right)$ з наступною активацією ПОЛ.

Інтенсифікація ПОЛ у результаті вільнорадикальних реакцій при ЗДА тісно пов'язана з порушенням стабільності ліпідного шару мембран еритроцитів.

У мембранах еритроцитів при ЗДА підвищується рівень холестерину, сорінгомієліну, фоссратидилхолінів, кардіоліпінів і знижується концентрація тригліцеридів, вільних жирних кислот, фоссратидилетаноламінів. Вказані зміни наростають паралельно ступеню тяжкості анемії.

При деоріциті заліза виявлено також підвищення в еритроцитарних мембранах загальних фоссроліпідів і вільного холестерину. Наслідком вказаної дезорганізації фоссроліпідного шару є поява мембранних пор, а при значному накопиченні продуктів гідролізу і перекисів ліпідів - розрив мембрани.

Процес дестабілізації мембран еритроцитів супроводжується заміщенням внутрішньоклітинного калію на іони натрію, що призводять до підвищення осмотичного тиску в еритроцитах, перерозподілу рідини з плазми крові у клітину з наступним розвитком набряку і гемолізу еритроцитів.

Продукти ПОЛ, викликаючи деструкцію еритроцитарних мембран і порушення їх фрункції, пригнічують також енергетичний обмін в еритроциті, що підтверджується зниженням при ЗДА еритроцитарного АТФ і ключового ферменту гліколізу - глюкозо-6-фоссратдегідрогенази.

Виражена і довготривала активація вільнорадикального окиснення ліпідів при ЗДА відбувається на тлі зміненої потужності АОСЗ. Дані літератури щодо рівня ферментів АОСЗ у дітей при ЗДА є неоднозначними.

Так, одні автори вказують, що у відповідь на активацію пОЛ при ЗДА, як компенсаторне явище, підсилюється активність антиокиснювальних ферментів - супероксиддисмутази, каталази, глутатіонпероксидази, глутатіонредуктази. Інші автори відзначають зниження вказаних ферментів, обґрунтовуючи це виснаженням АОСЗ внаслідок довготривалого десріциту заліза. $€$ дані, які свідчать про 
те, що при анемії в одного й того ж хворого може бути різнонаправлений характер змін у системі ферментів АОСЗ - підвищення рівня одного (супероксиддисмутази) і зниження іншого (глутатіонпероксидази). Некерована активація пол за умов відсутності належної відповіді АОСЗ впливає на фрункціональну здатність позаклітинних ензимів. Зокрема, підвищується активність білка - церулоплазміну, який має виражену окиснювальну дію.

Заслуговують на увагу дослідження процесів пол і стану АОСЗ у дорослих при анемії залежно від давності хвороби та супутньої патології. Встановлено, що підвищення рівня дієнових кон'югат та зниження активност каталази відбувалися паралельно давності захворювання і при поєднанні ЗДА з патологією серцево-судинної системи та частими простудними захворюваннями. Що стосується дітей, то подібних досліджень у доступній нам літературі ми не знайшли. Однак вірогідність аналогічного взаємозв'язку є високою, особливо у дітей шкільного віку, в яких дефіцит заліза має довготривалий, частіше аліментарний, характер.

Таким чином, дані літератури вказують на активацію пОЛ і розбалансованість у АОСЗ при ЗДА в дітей, що дає підставу віднести анемію до захворювань, які характе- ризуються мембранною патологією. Можна припустити, що ці процеси відіграють відповідну роль у механізмах виникнення ускладнень при ЗДА. Разом із тим, потребує подальшого вивчення стан ПОЛ - АОСЗ залежно від давності анемії, генезу десріциту заліза, наявності фонової патології.

Мембранодеструктивні й метаболічні зміни в еритроциті, які виникають внаслідок активації вільнорадикального окиснення ліпідів і зміни активності антиокиснювальних ферментів, пригнічують його фрункціональну активність, що сприяє наростанню гіпоксії та накопиченню в організмі токсичних метаболітів.

ПЕРСПЕКТИВИ ПОДАЛЬШИХ ДОСЛІДЖЕНЬ. Наведені матеріали переконують нас у необхідності подальшого вивчення процесів ПОЛ і стану АОСЗ у дітей при анемії, допоможуть розкрити патогенез багатьох патологічних процесів, оцінити ступінь ризику їх виникнення, прогнозувати особливості перебігу захворювання. Усунення оксидативного стресу допоможе підвищити ефективність профрілактичних і лікувально-реабілітаційних заходів. Разом із тим, потребує подальшого вивчення стан ПОЛ - АОСЗ залежно від давності анемії, генезу десріциту заліза, наявності фронової патології.

\section{СПИСОК ЛІТЕРАТУРИ}

1. Владимиров Ю. А. Перекисное окисление липидов в биологических мембранах / Ю. А. Владимиров, А. И. Арчаков. - Л., 1991.- 240 с.

2. Gregg L. Semenza. Oxygen sensing, hypoxia-iducible factors, and disease pathophysiology / L. Gregg Semenza // Pathology: Mechanisms of Disease. - 2014. - Vol. 9. - P. 47-71.

3. Rink L. Zincaltered immune function and cytokine production / L. Rink, H. Kirchner // J. Nutr. - 2008. - Vol. 130. - P. 1407-1411.

4. Нетюхайло Л. Г. Активні форми кисню (огляд літератури) / Л. Г. Нетюхайло, С. В. Харченко // Young Scientist. - 2014. - № 9 (12). - С. 131-135.

5. Levine S. A. Antioxidant adaptation: it's role in true radical pathology / S. A. Levine, P. M. Kidd. - London, 1986. - 362 p.

6. Walker A. R. Iron deficiency development and cognitive function (letter, comment) / A. R. Walker // Am. J. Clin. Nutr. 1996. - Vol. 64, No. 1.- P. 120-121.

7. Карімов І. 3. Окисна модисрікація білків і перекисне окислення ліпідів у розвитку метаболічної інтоксикації при патології/ І. 3. Карімов // Лаб. діагностика. - 2005. - № 1 (31). - С. 713.

8. Соодаева С. К. Окислительный стресс и антиоксидантная терапия при заболеваниях органов дыхания / С. К. Соодаева // Пульмонология. - 2006. - № 5. - С. 122-126.

9. Elsas L. J. Approach to inborn emors of metabolism / L. J. Elsas, L. Gladman, D. Ausiello // Cecil Medicine. Philadelphia, Pa: Saunders Elsevier, 2008. - P. 216.

10. Колішецька М. А. Роль порушень процесів перекисного окислення ліпідів та антиоксидантного захисту в бронхах морських свинок у ранній період формування експериментальної бронхіальної астми / М. А. Колішецька // Вісн. проблем біології і медицини. - 2013. - Т. 1 (104), вип. 4. - С. 143-146.

11. Frank K. L. Oxygen toxicity / K. L. Frank, D. Massoro // Amer. J. Med. - 1990. - Vol. 69, No. 1. - P. 117-126.

12. Kensuke R. The effect of vitamin E deficiency on some erythrocyte membrane properties / R. Kensuke, I. Makoto,
S. Masanori // J. Nutr. Sci. and Vitaminol. - 1985. - Vol. 31, No. 5. - P. 481-490.

13. Коровина Н. А. Применение антиоксидантов в педиатрической практике [Электронный ресурс] / Н. А. Коровина, И. Н. Захарова, Е. Г. Обыночная. - Режим доступа : http: media consilium/03_09/ Feb - 2004.

14. Курашвили В. А. Новые возможности предотвращения оксидативного стресса / В. А. Курашвили, Л. Майлэм // Журн. натуральной медицины. - 2001. - № 1. C. 7-14

15. Щербаков А. Е. Исследование показателей перекисного окисления липидов и антиоксидантной системы в комплексе мероприятий вторичной профилактики инсультов [Электронный ресурс] / А. Е. Щербаков. - Режим доступа : http: www. rusmedserv.com / 2000.

16. Перекисное окисление липидов при неврологической патологии у детей / Е. М. Васильева, М. И. Баканов, А. Е. Поддубная [и др.] // Клинич. лаб. диагностика. - 2005. - № 2. - C. 8-12.

17. Яворская В. А. Интенсивность процессов перекисного окисления липидов и активность антиоксидантных ферментов в эритроцитах при начальных фрормах сосудистых заболеваний головного мозга / В. А. Яворская, В. А. Малахов, А. М. Белоус // Неврологический вестн. - 1995. - Т. XXVII, вып. 3-4. - С. 15-17.

18. Зозуля Ю. А. Свободнорадикальное окисление и антиоксидантная защита при патологии головного мозга / Ю. А. Зозуля, В. А. Барабой, Д. А. Сутковой. - М. : Знание-М., 2000. -9 C.

19. Cord L. M. Superoxide production and human disease / L. M. Cord // J. Cell. Biochem. - 1991. - No. 5.- P. 68.

20. Michelson A. M. Biochemical and medical aspects of active oxygen / A. M. Michelson, K. Puget, P. Durosay. Baltomore; 1987. $-260 \mathrm{p}$.

21. Каплан О. В. Участие липидного компонента эритроцитов в газообмене и состояние дыхательной функ- 
ции крови при геморрагических анемиях / О. В. Каплан // Гематология и трансорузиология. - 1996.- № 4. - С. 15-17.

22. Казимирко В. К. Антиоксидантная система и ее функционирование в организме человека [Электронный ресурс] / В. К. Казимирко, В. И. Мальцев. - Режим доступа : http: www. health-ua.com /2004.

23. The role of lipid peroxidation and antioxidants in oxidative modification of LDL / H. Esterbauer, J. Gebicki, H. Puhl [et al.] // Free Radic. Biol. Med. - 1992. - No. 13. - P. 341-390.

24. Кашкалда Д. А. Окислительно-антиоксидантный гомеостаз у подростков, рожденных в семьях ликвидаторов последствий аварий на ЧАЭС / Д. А. Кашкалда, Г. А. Бориско // Современная педиатрия. - 2008. - № 3. - С. 11-14.

25. Нагорная Н. В. Оксидативный стресс: влияние на организм человека, методы оценки / Н. В. Нагорная, Н. А. Четверик // Здоровье ребенка. - 2010. - № 2 (23). - С. 140-145.

26. Galeotti N. Oxygen radicals: systemic events and disease processes / N. Galeotti, S. Barello, L. Mazott. -Basel, 1990. -150 p.

27. Julie K. Andersen. Oxidative stress in neurodegeneration: cause or consequence? / K. Julie Andersen // Nature Reviews Neuroscience. - 2004. - 5. - Р. 18-25.

28. Климанов В. В. Клиническая патофизиология детского возраста : руководство / В. В. Климанов, Ф. Г. Садыков. СПб., 1997. - 152 с.

29. Козлов Ю. П. Вільнорадикальне окислення ліпідів у біомембранах в нормі і патології / Ю. П. Козлов. - М. : Наука, 1995. - 120 с.

30. Оксидативный стресс у детей, проживающих в экологически неблагоприятных условиях. Возможности нейровитана в его коррекции / Н. В. Нагорная, Н. А. Четверик, А. В. Дубовая [и др.] // Современная педиатрия. - 2009. № 1 (23).- С. 124-129.

31. Буряк О. Г. Вільнорадикальне окиснення та нітроксидергічний дисбаланс у новонароджених із гострою дихальною недостатністю / О. Г. Буряк, Ю. Б. Ященко // Здоров'я дитини. - 2009. - № 3 (18).- С. 16-20.

32. Годованець О. І. Стан прооксидантної системи та систем антиоксидантного захисту ротової рідини у дітей із клінічними проявами гінгівіту за умов надмірного надходження в організм нітратів / О. І. Годованець, М. М. Рожко, А. М. Ерстенюк // Буковин. мед. вісн. - 2007. - Т. 11, № 2. - C. 31-33.

33. Литвин Б. С. Вплив комплексної медикаментозної терапії на окисний гомеостаз у дітей з вегетативними дисфункціями / Б. С. Литвин // Педіатрія, акушерство та гінекологія. - 2007. - № 2. - С. 16-18.

34. Олійник Я. В. Порушення перекисного окислення ліпідів та їх корекція у дітей, хворих на атопічний дерматит / Я. В. Олійник // Вісн. наук. дослідж. - 2007. - № 3. - С. 39-42.

35. Овсянникова Л. Антиоксидантные препараты: проблема выбора / Л. Овсянникова, E. Носач // Doctor. - 2003. - № 1. - С. 74-76.

36. Банадига Н. В. Активність ензимів антиоксидантного захисту у дітей із загостренням хронічної бронхолегеневої патології / Н. В. Банадига // Вісн. наук. дослідж. - 1997. № 4-5. - С. 85-86.

37. Лобода В. Ф. Структурно-фрункціональний стан клітинних мембран при хронічній гастродуоденальній та гепатобіліарній патології у дітей / В. Ф. Лобода // Вісн. проблем біології та медицини. - 1997. - № 9. - С. 55-57.

38. Halliwell B. Free radicals in biology and medicine / B. Halliwell, L. M. Gutteridge. - Oxford, 1989. - 130 p.

39. Minotti G. The requirement for iron (III) in the initiation of lipid peroxidation by iron (II) and hydrogen-peroxide / G. Minotti, S. D. Aust // J. Biol. Chem. - 1987. - Vol. 262, No. 3. - P. 1098-1104.

40. Суханова Г. А. Биохимия клетки / Г. А. Суханова, В. Ю. Серебров. - Томск : Чародей, 2000. - С. 91-142.

\section{REFERENCES}

1. Vladimirov, Yu.A., \& Archakov, A.I. (1991). Perekisnoe okislenie lipidov $v$ biologicheskikh membranakh [Peroxide oxidation of lipids in biological membranes]. [in Russian].

2. Gregg, L. Semenza (2014). Oxygen sensing, hypoxiainducible factors, and disease pathophysiology. Pathology: Mechanisms of Disease, 9, 47-71.

3. Rink, L., \& Kirchner, H. (2008). Zincaltered immune function and cytokine production. J. Nutr., 130, 1407-1411.

4. Netiuhailo, L.H., \& Kharchenko, S.V. (2014). Aktyvni formy kysniu (ohliad literatury) [Active forms of oxygen (review of literature)]. Young Scientist, 9,131-135 [in Ukrainian].

5. Levine, S.A., \& Kidd, S.A. (1986). Antioxidant adaptation: it's role in true radical pathology. London.

6. Walker, A.R. (1996). Iron deficiency development and cognitive function (letter, comment). Am. J. Clin. Nutr., 64, 1 , 120-121.

7. Karimov, I.Z. (2005). Okysna modyfikatsiia bilkiv i perekysne okyslennia lipidiv u rozvytku metabolichnoi intoksykatsii pry patolohii [Oxidative modification of proteins and peroxide oxidation of lipids in the development of metabolic intoxication with pathology. Laboratorna diahnostyka - Laboratory Diagnostics,1 (31),7-13 [in Ukrainian].

8. Soodayeva, S.K. (2006) Okislitelnyy stress i antioksidantnaya terapiya pri zabolevaniyakh organov dykhaniya [Oxidative stress and antioxidant therapy in respiratory diseases]. Pulmonologiya - Pulmonology, 5, 122-126 [in Russian].
9. Elsas, L.J., Gladman, L., \& Ausiello, D. (2008) Approach to inborn emors of metabolism. Cecil Medicine. Philadelphia, Pa: Saunders Elsevier, 216.

10. Kolishetska, M.A. (2013). Rol porushen protsesiv perekysnoho okyslennia lipidiv ta antyoksydantnoho zakhystu $v$ bronkhakh morskykh svynok u rannii period formuvannia eksperymentalnoi bronkhialnoi astmy [The role of violations of the processes of lipid peroxidation and antioxidant defense in guinea pig bronchuses in the early period of the formation of experimental bronchial asthma]. Visnyk problem biolohii i medytsyny - Bulletin of Biology and Medicine Problems, 1 (104),4,143-146 [in Ukrainian].

11. Frank, K.L., \& Massoro, D. (1990). Oxygen toxicity. Amer. J. Med.,1, 117-126.

12. Kensuke, R., Makoto, I., \& Masanori, S. (1985). The effect of vitamin $\mathrm{E}$ deficiency on some erythrocyte membrane properties. J. Nutr. Sci and Vitaminol., 31 (5), 481-490.

13. Korovina, N.A., Zakharova, I.N., \& Obynochnaya, E.G. (2004). Primenenie antioksidantov v pediatricheskoy praktike [Application of antioxidants in pediatric practice]. - Retrieved from: http: media consilium/03_09/ Feb.

14. Kurashvili, V.A., \& Maylem, L. (2001). Novye vozmozhnosti predotvrashcheniya oksidativnogo stressa [New opportunities for the prevention of oxidative stress]. Zhurnal naturalnoy meditsyny - Journal of Natural Medicine, 1, 7-14 [in Russian]. 
15. Shcherbakov, A.E. (2000). Issledovanie pokazateley perekisnogo okisleniya lipidov i antioksidantnoy sistemy $\mathrm{v}$ komplekse meropriyatiy vtorichnoy profilaktiki insultov [Investigation of indicators of lipid peroxidation and antioxidant system in the complex of secondary prevention measures of stroke]. - Retrieved from: http: www. rusmedserv.com [in Russian].

16. Vasilyeva, E.M., Bakanov, M.I., \& Poddubnaya, A.E. (2005). Perekisnoe okislenie lipidov pri nevrologicheskoy patologii u detey [Peroxidation of lipids in neurological pathology in children]. Klinicheskaya laboratornaya diagnostika - Clinical Laboratory Diagnostics, 2, 8-12 [in Russian].

17. Yavorskaya, V.A., Malakhov, V.A., \& Belous, A.M. (1995). Intensivnost protsessov perekisnogo okisleniya lipidov i aktivnost antioksidantnykh fermentov $v$ eritrotsitakh pri nachalnykh formakh sosudistykh zabolevaniy golovnogo mozga [Intensity of lipid peroxidation processes and activity of antioxidant enzymes in erythrocytes in the initial forms of vascular diseases of the brain]. Nevrologicheskiy vestnik Neurological Bulletin, XXVII, 3-4, 15-17.

18. Zozulya, Yu.A., Baraboy, V.A., \& Sutkovoy, D.A. (2000). Svobodnoradikalnoe okislenie i antioksidantnaya zashchita pri patologii golovnogo mozga [Free radical oxidation and antioxidant defense in brain pathology]. Moscow: Znanie [in Russian].

19. Cord, L.M. (1991). Superoxide production and human disease. J. Cell. Biochem., 5, 68.

20. Michelson, A.M., Puget, K., \& Durosay, P. (1987). Biochemical and medical aspects of active oxygen. Baltomore, 260.

21. Kaplan, O.V. (1996). Uchastie lipidnogo komponenta eritrotsitov $v$ gazoobmene i sostoyanie dykhatelnoy funktsii krovi pri gemoragicheskikh anemiyakh [Participation of the lipid component of erythrocytes in gas exchange and the state of respiratory function of blood in hemorrhagic anemia]. Gematologiya i transfuziologiya - Hematology and Transfusiology, 4,15-17 [in Russian].

22. Kazimirko, V.K., \& Maltsev, V.I. (2004). Antioksidantnaya sistema i ee funktsionirovanie $v$ organizme cheloveka [Antioxidant system and its functioning in the human body]. - Retrieved from: http: www.health-ua.com [in Russian]

23. Esterbauer, H., Gebicki, J., \& Puhl, H. (1992). The role of lipid peroxidation and antioxidants in oxidative modification of LDL. Free Radic. Biol. Med, 13, 341-390.

24. Kashkalda, D.A., \& Borisko, G.A. (2008). Okislitelno-antioksidantnyy gomeostaz u podrostkov, rozhdennykh v semyakh likvidatorov posledstviy avariy na ChAES [ Oxidative-antioxidant homeostasis in adolescents born in the families of the liquidators of the consequences of accidents at the ChNPP]. Sovremennaya pediatriya - Modern Pediatrics, 3,11-14 [in Russian].

25. Nagornaya, N.V., \& Chetverik, N.A. (2010). Oksidativnyy stress: vliyanie na organizm cheloveka, metody otsenki [Oxidative stress: influence on the human body, evaluation methods] Zdorovye rebenka - Child's Health, 2, 23, 140-145 [in Russian].

26. Galeotti, N., Barello, S., \& Mazott, L. (1990). Oxygen radicals: systemic events and disease processes. Basel, 150.

27. Julie Andersen, K. (2004). Oxidative stress in neurodegeneration: cause or consequence? Nature Reviews Neuroscience, 5, 18-25.

28. Klimanov, V.V., \& Sadyikov F.G. (1997). Klinicheskaya patofiziologiya detskogo vozrasta: rukovodstvo [Clinical pathophysiology of childhood: leadership]. St. Petersburg [in Russian].
29. Kozlov, Yu.P. (1995). Vilnoradykalne okyslennia lipidiv u biomembranakh v normi i patolohii [Free radical oxidation of lipids in biomembranes in normal and pathology]. Moscow: Nauka [in Ukrainian].

30. Nagornaya, N.V., Chetverik, N.A., \& Dubovaya, A.V. (2009). Oksidativnyy stress u detey, prozhivayushchikh v ekologicheskikh neblagopriyatnykh usloviyakh. Vozmozhnosti neyrovitana $v$ ego korektsii [Oxidative stress in children living in environmentally unfavorable conditions. Neurotan potential in his correction]. Sovremennaya pediatriya - Modern Pediatrics, 1,(23),124-129 [in Russian].

31. Buriak, O.H., \& Iashchenko, Yu.B. (2009). Vilnoradykalne okysnennia ta nitroksyderhichnyi dysbalans u novonarodzhenykh iz hostroiu dykhalnoiu nedostatnistiu [Free radical oxidation and nitroxydergic imbalance in newborns with acute respiratory insufficiency]. Zdorovia dytyny - Health of a Child, 3,(18),16-20 [in Ukrainian].

32. Hodovanets, O.I., Rozhko M.M., \& ErsteniukA.M. (2007). Stan prooksydantnoi systemy ta system antyoksydantnoho zakhystu rotovoi ridyny $u$ ditei iz klinichnymy proiavamy hinhivitu za umov nadmirnoho nadkhodzhennia v orhanizm nitrativ [The state of the prooxidant system and antioxidant mouthwash systems in children with clinical manifestations of gingivitis under conditions of excessive intake of nitrates in the body]. Bukovynskyi medychnyi visnyk - Bukovyna Medical Bulletin,11 (2),31-33 [in Ukrainian].

33. Lytvyn, B.S. (2007). Vplyvkompleksnoi medykamentoznoi terapii na okysnyi homeostaz u ditei z vehetatyvnymy dysfunktsiiamy [Influence of complex medical therapy on oxidative homeostasis in children with autonomic dysfunctions]. Pediatriia, akusherstvo ta hinekolohiia-Pediatrics, Obstetrics and Gynecology, 2, 16-18.

34. Oliinyk, Ya.V. (2007). Porushennia perekysnoho okyslennia lipidiv ta yikh korektsiia u ditei, khvorykh na atopichnyi dermatyt [Disorders of lipid peroxidation and their correction in children with atopic dermatitis]. Visnyk naukovykh doslidzhen Bulletin of Scientific Researches, 3, 39-42 [in Ukrainian].

35. Ovsyannikova, L., \& Nosach, E. (2003). Antioksidantnye preparaty: problema vybora [ Antioxidant drugs: the problem of choice ]. Doctor, 1, 74-76 [in Russian].

36. Banadyha, N.V. (1997). Aktyvnist enzymiv antyoksydantnoho zakhystu u ditei iz zahostrenniam khronichnoi bronkholehenevoi patolohii [Activity of enzymes of antioxidant defense in children with acute exacerbation of chronic bronchopulmonary pathology]. Visnyk naukovykh doslidzhen - Bulletin of Scientific Researches, 4-5, 85-86 [in Ukrainian].

37. Loboda, V.F. (1997). Strukturno-funktsionalnyi stan klitynnykh membran pry khronichnii hastroduodenalnii ta hepatobiliarnii patolohii $u$ ditei [Structural-functional state of cell membranes in chronic gastroduodenal and hepatobiliary pathology in children]. Visnyk problem biolohii ta medytsyny Bulletin of Biology and Medicine Problems, 9, 55-57 [in Ukrainian].

38. Halliwell, B., \& Gutteridge, L.M. (1989). Free radicals in biology and medicine. Halliwell - Oxford.

39. Minotti, G., \& Aust, S.D. (1987). The requirement for iron (III) in the initiation of lipid peroxidation by iron (II) and hydrogen-peroxide. J. Biol. Chem., 262, 3, 1098-1104.

40. Sukhanova, G.A., \& Serebrov, V.Yu. (2000). Biokhimiya kletki [Cell biochemistry]. Tomsk: Charodey.

Отримано 03.01.18 